Para enlazar con este artículo / To link to this article:

http://dx.doi.org/10.6035/MonTI.2019.11.5

Para citar este artículo / To cite this article:

Remael, Aline; Pilar Orero; Sharon Black \& Anna Jankowska. (2019) "From translators to accessibility managers: How did we get there and how do we train them?" In: Tolosa Igualada, Miguel \& Álvaro Echeverri (eds.) 2019. Porque algo tiene que cambiar. La formación de traductores e intérpretes: Presente E futuro / Because something should change: Present \& Future Training of Translators and Interpreters. MonTI 11, pp. 131-154.

\title{
FROM TRANSLATORS TO ACCESSIBILITY MANAGERS: HOW DID WE GET THERE AND HOW DO WE TRAIN THEM? ${ }^{1}$
}

\author{
Aline Remael \\ aline.remael@uantwerpen.be \\ University of Antwerp \\ Pilar Orero \\ Pilar.Orero@uab.cat \\ Universitat Autònoma de Barcelona \\ Sharon Black \\ Sharon.Black@qub.ac.uk \\ Queen's University Belfast \\ Anna Jankowska \\ Anna.Jankowska@uab.cat \\ Universitat Autònoma de Barcelona
}

\begin{abstract}
Translation continues to reinvent itself. Different human actors and non-human actants drive this change, generating new forms of translation and diverse professional profiles. Audiovisual Translation (AVT) and Audiovisual Translation Studies (AVTS) have always been at the centre of these developments: AVT has been technology and industry-driven from the start and AVTS has incorporated technological and societal change as well as the forces that propel it from its inception. Meanwhile, AVT has incorporated media accessibility and has moved beyond the domain of audiovisual media in the strict sense
\end{abstract}

1. Acknowledgements: This article is part of the research outcome from the EU funded KA2 project ACT, Accessible Culture and Training with the reference 2015-1-ES01-KA203015734. Pilar Orero and Anna Jankowska are members of TransMedia Catalonia, research group funded by Generalitat de Catalunya under the SGR funding scheme (2017SGR113). 
into the provision of access to live cultural events. The present article offers some conceptual tools for understanding these developments as well as the actant-driven processes that underlie them. It traces recent developments in AVT and explains how they have given rise to the aforementioned new professional practices and profiles. It ends on an extensive case study, centring on the ACT European Erasmus+ project, which has identified and defined the emerging profile of the accessibility manager, and developed a tailor-made MOOC training course for it.

\section{Resumen}

La traducción continúa reinventándose a sí misma. Diferentes actores humanos y actantes no humanos impulsan este cambio, generando nuevas formas de traducción y perfiles profesionales diversos. La Traducción Audiovisual (AVT) y los Estudios de Traducción Audiovisual (AVTS) siempre han estado en el centro de estos desarrollos: la AVT ha sido impulsada por la tecnología y la industria desde el principio y los AVTS, desde su inicio, han incorporado el cambio tecnológico y social, así como las fuerzas que lo impulsan. Mientras tanto, la AVT ha incorporado la accesibilidad de los medios y ha ido más allá del dominio de los medios audiovisuales en sentido estricto para proporcionar acceso a eventos culturales en vivo. El presente artículo ofrece algunas herramientas conceptuales para entender estos desarrollos, así como los procesos impulsados por actantes que los sustentan. Delinea los desarrollos recientes en AVT y explica cómo han dado lugar a las nuevas prácticas y perfiles profesionales antes mencionados. Termina con un extenso estudio de caso, centrado en ACT -un proyecto europeo Erasmus+- que ha identificado y definido el perfil emergente del mánager de accesibilidad, y ha desarrollado un curso online (MOOC) a medida para su formación.

Keywords: Translation studies. Accessibility. Audio description. Audiovisual translation.

Palabras clave: Estudios de traducción. Accesibilidad. Audiodescripción. Traducción audiovisual. 


\section{Introduction}

The first reflex of Translation Studies (TS), a young area of study in the 1970s, was to carve itself out a place among the respected sciences and define its paradigm. In parallel, departments or schools of TS began to be established, in line with the view of Holmes (1972: 67) that a new science must develop its own communication channels and institutions. However, meanwhile, translation and, consequently, TS has continued to redefine itself, while target users, translation providers, and technology too appear to diversify continually. An immediate consequence of this state of affairs is that translator profiles continue to change and diversify as well. However, looking back, this could be considered as a chronicle of an announced change, so to speak.

As early as 1972 James Holmes indicated in the above-mentioned seminal article "The Name and Nature of Translation Studies" (1972: 68) that an increasing number of disciplines were becoming involved in the then very young paradigm of TS: linguistics, philosophy of language, literary studies, but also information technology, logic and mathematics. By now that number has grown exponentially, and has led to discussions about TS being either multidisciplinary or an "interdiscipline" (Snell-Hornby, Pöchhacker \& Kaindl 1994). In addition, TS has seen many 'turns', and new ones, such as the 'technological turn', keep being added, an evolution that has prompted Tymoczko (2007: 78) to write:

[...] there are no necessary and sufficient conditions that can identify all translations and that at the same time exclude all non-translations across time and space and $[\ldots]$ translation theory has [...] shown a continual tendency to expand the purview of translation, with a concomitant expansion of the scope of translation research.

In addition, and in apparent contradiction with the above, a fairly recent key word in TS is 'convergence', one of the topics of the Trieste 2016 TransInt conference "Translation and Interpreting: Convergence, Contact, Interaction". It denotes the awareness that translation and interpreting are in many ways 'converging', which seems to indicate that two opposite trends are at work at once, or maybe they are two sides of the same coin. Moreover, these contradictory or 
complementary movements of divergence and convergence are not limited to the traditional subdomains of Translation Studies ("proper") and Interpreting studies. In fact, another interesting conference title, that of the Olomouc Translation and Interpreting Forum TIFO (2017), "Translating the wor(1)d: Beyond language", suggests that translation today has moved beyond linguistic barrier breaking into truly intersemiotic forms of communication.

In this article we offer one view on what we think is happening, what is causing these recent developments, how they impact users and producers of translation, and, most of all, how they impact training. The latter will be illustrated with a case study, the ACT MOOC, developed within the framework of the European Erasmus+ project Accessible Culture and Training.

\section{The continuous reinvention of translation: a methodological framework}

In order to understand these evolutions in all their complexity, a framework is required that is sufficiently broad to encompass the diversity that confronts translation scholars and trainers today, and that offers concepts that will allow them to explain it, deal with it and allow society to benefit from it.

A first step is to embrace complexity as complexity and as a source of potential beneficial developments rather than as a threat. Translation, whatever form it takes, is bound to remain an important impacting communication factor in today's globalized world as it generates connections across communities and across continents thereby promoting development (see also Marais 2013). To give but one example: a society in which information is available only to those who have full access to written verbal and other visual information that is communicated via the internet, is a much poorer society than one in which media accessibility, or forms of audiovisual translation (AVT) such as audio description and audio subtitling, also provide access to population groups that must rely on auditory channels for information gathering and full participation in society.

However, whereas translation has an impact on society, society has an equally strong impact on translation. The movement between the two is fundamentally dialogical, and in order to understand the forms translation takes today, it is crucial to understand the dialectics that produce these different forms as well as the actors that cause change: "society" is too abstract a concept. According to the sociologist Latour (2005), the father of Actor Network theory, society does not actually exist. It is forever "becoming" and, similarly, one might say that translation does not exist. Some form of translation is no doubt at the core of many forms of communication but as such it seems to have lost 
its traditional identity. There is no such thing as Jakobson's (1959) "translation proper".

Marais $(2013,2014)$ was probably one of the first, if not the first, to apply complexity theory, or the study of complex systems, to Translation Studies. He promotes complexity theory as a theoretical framework because it opposes all forms of reductionism, which is also why he questions the usefulness of adding one 'turn' to the next in TS when new phenomena need to be explained. Each new 'turn' reduces TS to something else. Complexity theory, by contrast, sees reality as consisting of different levels of existence that emerge from one another whereby each new level, or phenomenon, "[...] is the form the previous level takes through particular new interactions amongst parts of the previous level or through particular new organisations between the parts." (2014: 28).

To make this concrete, one could say that fansubbing is a form of subtitling. It is the result of interactions between constituents of older forms of subtitling but taken to a different level and into a different context. The new context is that of subtitling by prosumers who make and use the subtitles, rather than, for instance, consumers (viewers) who use subtitles created by producers (broadcasters). More generally, all forms of translation are the result of interactions that cannot be explained by reducing them to their constituent parts, be it language, literature, culture, technology or any other constituents formerly represented by as many "turns" in TS. Translation in all its forms can only be understood as an "emergent phenomenon", a specific interaction of its parts in varying configurations. In brief, in order to understand where translation is headed, and what consequences this may have for training, we need to study the variables from which it emerges and evolves (Marais 2014: 32).

This idea that research should focus on explaining the processes and interactions that produce phenomena (in our case, translations), is shared by the branch of sociology known as Actor Network Theory (ANT). ANT is not new to Translation Studies (see e.g. Abdallah 2011, Buzelin 2005, Eardley-Weaver 2013, Folaron \& Buzelin 2007, Risku \& Windhager 2013) and it is congruent with the way Marais' interpretation of complexity theory conceptualizes translation. However, it edges closer to what could be considered a research "methodology". Latour (2005: 5) opposes traditional sociology that starts from the idea that the existence of specific social groups can help explain societal phenomena. He considers these social aggregates as what should actually be explained. In ANT, a structure or institution, such as a union, is not predetermined but seen as emerging from the actions and the relations of its actors (Abdallah 2011: 175). Latour therefore proposes to analyse processes rather than products in order to account for the hybrid character of the latter (Buzelin 
2005: 196) and, broadly speaking, that is what the above-mentioned TS scholars making use of ANT in their research have done to explain the different forms translation can take: study the social process to explain the product.

What is particularly interesting for the study of translation today, which is not only impacted by globalization but also by digitization, or technology more generally, is that, as Risku \& Windhager 2013: 36) write, "According to Latour, social processes (like the dynamics of innovation and stabilisation) can only be adequately understood through the meticulous observation of interactions between human actors and non-human artefacts - referred to collectively as "actants" (our emphasis). In other words, it is not only the interaction of human actors that produces change but also the interaction of human actors and non-human actants. In translation today, the influence of non-human actants on the translation process and product, in other words, on what is translation, cannot be underestimated.

In brief, whereas complexity theory offers TS a framework for the study of translation as a broad semiotic, emerging phenomenon, ANT introduces the concept of actants, which allows for the study of non-human actors in interaction with human actors, and of the impact of this interaction on the evolution and hybridization of translation. Today, the relations between human and non-human actors are still mostly seen in terms of interaction rather than true dialogicity between equals. However, that too is bound to change. In his book on dialogicity, in which Linell (2009) defines the concept as the central feature in the way human knowledge develops, he still focuses on the dialogic interaction between what Latour would call "actors". Nevertheless, Linell already envisages further change in his brief chapter on the future of Artificial Intelligence (2009: 348-350), where he tentatively offers a vision of the future in which interactions between human and non-human actants become a true form of dialogue. Meanwhile this has been taken up by authors such as Schwab (2016), writing on "the fourth industrial revolution" who point out that in the Internet of Things this has become a reality. Today, non-human actants interact with each other and the interactions between actor and actant are already taking the form of a true dialogue. Applying some of the concepts and the framework developed so far, the next section considers some of the actors and actants that have been crucial in the expansion of (audiovisual) translation into (media) accessibility.

\section{The continuous reinvention of translation: actants}

Not only translation but also Translation Studies has been diversifying to the rhythm of change in society as determined by the actors driving this change. 
However, Audiovisual Translation Studies (AVTS) has always been the odd man out. Broadly speaking, and in a simplified rendering of history, one could say that TS researchers originally focused on a number of clearly delineated research topics and were concerned with developing TS theories and methodologies to tackle them, all the while creating a discipline in its own right. The topics included legal translation, technical translation, literary translation and translation for the theatre. The traditional frameworks for studying translation that first saw the light went from prescriptive to descriptive and/or functional, with discussions centring on such issues as equivalence, norms, skopos, text typologies, the text as Informationsangebot, translation methods, and didactic concerns related to these.

In spite of the omnipresence of audiovisual media in many areas of society and in peoples' homes, they originally attracted limited attention from TS and AVT was actually not considered to be translation or not taken seriously. One reason for this was that it involves adapting the source text to various degrees; another was that it was, out of necessity, technologically oriented and not very equivalence-prone. Not surprisingly, research in AVT was therefore initially quite dispersed. Though there are articles making reference to AVT before 1991, it may have been Luyken et al. (from Communication Studies) who, with their book Overcoming Language Barriers in Television: Dubbing and Subtitling for the European Audience, assembled in one volume all the issues related to what would become the two most studied audiovisual translation modalities: dubbing and subtitling. Their publication, which was closer to industry than to science, became one of the actants leading the field of AVT into the study of the media sector and professional experience.

In another important move, the European Association for Studies in Screen Translation (https://www.esist.org) ESIST was created, as early as 1995, with its goal "to facilitate the exchange of information and to promote professional standards in the training and practice of screen translation". The emphasis on professional standards and training by ESIST explicitly identified the media industry, and by extension its interest in technology, as an actant. This has been reflected in the hybrid nature of the most popular AVT conferences to date (e.g. Languages and the Media and Media for All) where industry and academia share a common space to debate new developments from a truly interdisciplinary perspective. While TS considered AVT to be a subordinate field of "insubordinate" scholars, AVT came of age embracing rather than dismissing novelties and recognizing them as actants that would co-determine its fate. In AVT even "format" is an actant since it determines the shape different forms of AVT take. In other words, we believe that the immediate impact of industrial actors and 
actants made itself felt in AVT and was acknowledged in AVTS before it was in other fields of TS.

Through its conscious embracing of industry and technology, AVTS has also kept pace with change, including new forms of audiovisual translation that have meanwhile come into existence. In a certain way, some would say that AVT thereby even moved outside of its comfort zone. Not only are the joint impact of actants from industry and technology now acknowledged, but so are other multiple actants, themselves often technology driven, such as consumers turned into prosumers and activists demanding that AVT serve their needs, thereby turning AVT into a form of media accessibility. As AVTS aims to keep pace with these developments it must also turn increasingly to the study of these actants, to understand the types of translation they demand and produce. What is more, translation, and TS more generally, are now facing similar challenges as the demands of the translation industry appear to be catching up with the traditional theoretical frameworks of translation. One could even say that the growing connections between different types of translation and translation research relying on technology (which is now even impacting on literary translation), have moved AVT and its development into media accessibility from the periphery into the centre of TS concerns.

It has also produced connections between forms of translation that were formerly considered quite distinct (hence the "convergence" theme so prominent in different conferences today - see section 1). One example is the rise of live interlingual subtitling and its affinities with simultaneous interpreting; another is the development of machine translation in very disparate translation forms, audiovisual and other. Within TS the rise of process and reception studies runs parallel between non-AVT and AVT-focused studies as the impact of different actors on the translation process attracts increasing attention. However, the evolution does not stop. As AVTS has scrambled to remain abreast of developments, new forms of (audiovisual) translation also continue to mould AVT to fit very different formats and platforms, now both inside and outside what one could call audiovisual media "proper".

AVTS identified media and technology as actants virtually from its inception and in the $21^{\text {st }}$ century both have enjoyed exponential growth due to the development of the Information Society. Today, in the era of globalisation with its multiplicity of users and prosumers, as well as growing multilingualism and multiculturalism, new forms of audiovisual translation and new formats are being appropriated by new actants. They are being repurposed for different audiences and different environments, promoting an inclusive society. Indeed, all forms of communication today must strive to accomplish inclusion for all, 
a development that was sanctioned by the UN Convention on the Rights of Persons with Disabilities (CRPD) (United Nations 2008), which made access to media, entertainment and information a human right. These developments also encompass events outside the traditional audiovisual media that are the domain of AVT. One quickly developing new environment in which audiovisual translation as media accessibility is making much headway is that of live cultural events, or what below will be termed "live events for the scenic arts". The type of media accessibility developed within AVT in the form of subtitling for deaf and hard of hearing people or audio-description for blind people is thereby entering a field where another form of access studies was already active: that is, the study of the accessibility of physical environments based on the principle of universal design (Rose Connell, Jones, Mueller et al. 1997). Media accessibility as developed from AVT and applied to live events, and the scenic arts in particular, is mostly concerned with accessible content, as are the professionals supplying translations for access. The question is: how does one merge the two approaches, and what is the place of (audiovisual) translators in this? The smooth joint operation of content accessibility within physical buildings, which can be seen as another new "format" must be managed by a professional who does not yet exist.

This separation between the traditional study of accessibility and the development of accessibility aiming to provide access to content has thereby given rise to the problem identified by the team who joined forces in 2015 to study Accessibility in the Scenic Arts, as well as its training in the EU-funded project ACT (http://pagines.uab.cat/act/).

\section{Case study: the accessibility manager for the scenic arts}

We have demonstrated above that just as other forms of translation and AVT are continually evolving and being redefined, media accessibility is rapidly expanding and diversifying, opening up access not only to television, film and online content, but also in the context of the scenic arts, with an increasingly diverse range of electronic and digital media providing audiences with intersemiotic translations of cultural performances and events. Another result of these developments is that the scope of AVTS is widening and increased scholarly attention is focused on multimodality in translation and translation as an intersemiotic, intersensorial form of communication (Eardley-Weaver 2014: 6). Furthermore, as is highlighted in the previous section, for all audiences to be able to enjoy full access to translated multimodal texts, the design of the physical environment in which the texts are consumed is a significant actant. Given these developments, there is a need to redefine the roles of 
translation providers and examine the tasks involved in creating translated multimodal texts that are accessible to all audiences. This section focuses on the role of one particular translation provider or manager: the accessibility manager for the scenic arts. It considers the actors and actants which have created the need for this new profile and explains how the ACT project has addressed this need by defining the skills and competencies of the role and developing training for the role by creating a curriculum and a MOOC on arts accessibility.

\subsection{What lies at the source of this new profile}

Among the principal actors driving the imperative to provide accessible arts, culture and media for all are the increasingly diverse citizens of the EU. Added to the many displaced people or those in need of linguistic accessibility are the estimated 80 million European citizens with disabilities (European Parliament 2016). Moreover, the EU population is ageing, with the number of people aged 65 or over having increased by 2.4\% in the decade between 2006 and 2016 (Eurostat 2017). As the EU's population ages, the number of people with disabilities or age-related internet access difficulties is expected to increase to 120 million by 2020 (European Parliament 2016). Thus, as the proportion of EU citizens depending on accessibility grows, there is a concomitant increase in the demand for inclusive arts and media accessibility.

As well as being driven by audience demand, the actant introduced earlier at the end of section 2; namely, that of technological progress, has generated a proliferation of innovative methods for the multisemiotic translation of art forms aimed at providing all audiences with inclusive, multisensory experiences of the arts (Eardley-Weaver 2015a, 2015b). Traditional written verbal translations in the form of conventional surtitles and translated libretti, programme notes and synopses of performances now coexist with multifarious translation modalities, such as audio description, audio subtitles, touch tours, sign language interpreting and intralingual theatre captioning. Technological advancements enable patrons to access the arts by for example watching a sign language interpreted introductory video on a venue's website in advance of attending a performance, or using individual devices such as audio description headsets, tablets on the backs of auditorium seats, smartphones and smart glasses displaying closed captions (Eardley-Weaver 2015a), mobile apps (Szarkowska, Jankowska \& Krejtz 2016) and interactive haptic technology for immersive theatre experiences (Wisema, Van der Linden \& Spiers 2017; Spiers, Van der Linde, Oshodi et al. 2015). Moreover, patrons attending relaxed 
performances ${ }^{2}$ can follow the stage action on screens in other areas of the venue, such as the designated quiet area, and the display of the live stream can even be delayed by a few seconds to provide a smoother transition for patrons moving from the auditorium to the quiet area $^{3}$.

Thus, a coordinator is required to manage these multiple and complex networks of multisemiotic translation processes which "interact and relate to each other as well as to other processes such as marketing and box office activities" (Eardley-Weaver 2014: 10), which are also collaborative as they involve various agents and links, and which require specialist knowledge of "many tools that are part of modern translation work" (Risku \& Windhager 2013: 36). Moreover, given that accessibility facilities still tend to be regarded as additional services which are separate to the performance itself, which incur additional costs and are provided specifically to cater to the needs of a small subset of the audience (Eardley-Weaver 2014: 269), arts accessibility experts, or managers are needed to raise awareness that accessibility should form an integral part of the production of arts events from their inception and that universally inclusive arts events are for everyone and benefit everyone.

Moreover, other actors working at grassroots level and creating the context for the development of the professional profile of the arts accessibility expert are the countless groups and associations acting for the rights of people with disabilities. The tireless efforts of these actors have prompted United Nations (UN) and European Union (EU) bodies to adopt legally-binding agreements between states recognising the rights of people with disabilities. As such, the aforementioned international bodies and state institutions implementing the obligations at national levels and the legal instruments themselves also have

2. Theatres in the UK and the USA began to offer relaxed performances less than a decade ago, but relaxed performances now take place in many venues (Fletcher-Watson 2015). Relaxed performances were originally primarily intended for patrons with autism, dementia, learning or cognitive disabilities, but there is increasing awareness of their appeal to wider audiences. The main features of a relaxed performance are: patrons are provided with a visual story or tour of the event in advance so that they know what to expect; patrons are free to enter and leave the auditorium during the performance when they wish; patrons are warned of any loud noises and noise levels are generally reduced; there are no flashing or strobe lights; house lights are kept on during the performance; a designated quiet area is provided with a live stream of the show; and venue staff are aware of the importance of creating a warm, relaxed atmosphere and provide patrons with additional assistance (Fletcher-Watson 2015, Kempe 2015).

3. Information on delaying the live stream of a performance by a few seconds was provided by the Creative Director of The Metropolitan Arts Centre (The MAC), Simon Magill, during the filmed interview on accessibility at The MAC in Belfast for the ACT MOOC (presented in section 4.2) in Feb 2018. 
become actants, stimulating or even enforcing the developments described in the previous paragraph ${ }^{4}$.

In sum, the principal actors and actants generating the need for this new profile of the arts accessibility manager are the audiences themselves, which increasingly depend on and expect greater accessibility, the technological advancements driving the rapid expansion of arts translation modalities increasingly provided in combination with the aim of achieving universal arts inclusion, the groups and associations advocating for the rights of persons with disabilities, and the legislative obligations and the institutions creating and implementing them. However, questions arise as to whether arts venues are now responding by putting accessibility managers in place, and as to the current state of development of this role. With the aim of answering these questions, the ACT project, which is further discussed below in section 4.2, has gathered data on accessibility management in the scenic arts in the partner countries across Europe (Spain, Belgium, Austria and the UK). Responses were obtained from 75 venues, and the results showed that with the exception of two pioneering roles of Access and Inclusion Coordinators introduced in Northern Ireland, arts accessibility management is currently lacking (Eardley-Weaver

4. The first international treaty dedicated to protecting and promoting the rights of people with disabilities is the UN Convention on the Rights of Persons with Disabilities (CRPD) (United Nations 2008). The CRPD was ratified by the EU in December 2010, marking the first time in history that the EU had become a party to an international human rights treaty (European Commission 2011). All 27 EU countries signed the CRPD in 2007, and only Ireland has not yet ratified it. $22 \mathrm{EU}$ countries have also signed its Optional Protocol and 22 have ratified it (European Commission n.d.). It covers civil, political, social, economic, legal and cultural rights and aims to break down the barriers that people with disabilities face in their everyday lives that prevent them from enjoying full human rights on an equal basis with all other citizens. As part of its work to meet the commitments and obligations of the CRPD at a European level, the EU has created the European Accessibility Act 2015 and the European Disability Strategy 2010-2020. The European Accessibility Act aims "to improve the functioning of the internal market [for accessible products and services] by removing barriers created by divergent legislation" (European Parliament and Council 2015). The European Disability Strategy 2010-2020 provides a framework for action outlining how the EU and national governments can commit to breaking down barriers for people with disabilities so they can enjoy equal rights with other EU citizens, ensuring for example better access to goods, services and assistive devices. As for the provision of accessible audiovisual media services in Europe, this is covered by the European Audiovisual Media Services Directive. Article 46 of the directive states that access to audiovisual media forms part of the "right of persons with a disability and of the elderly to participate and be integrated in the social and cultural life of the Union" and specifies that "the means to achieve accessibility should include, but need not be limited to, sign language, subtitling [and] audio-description" (European Parliament and Council 2010). 
2016). Moreover, qualitative data indicated that, across the partner countries, staff members responsible for accessibility rarely hold roles that are purely dedicated to access, and usually work in education or marketing departments with some accessibility duties. Furthermore, a study conducted in Catalonia which gathered survey data from 44 public playhouses found that access facilities were managed by different departments in the same venue which often did not communicate with each other, and with no one person in charge of coordinating accessibility (Orero 2017). Therefore, it seems that coordinating accessibility is currently regarded as a set of ancillary tasks rather than as a management role.

\subsection{Training for this new profile}

It is clear that there is now an imperative to establish the role of accessibility manager for the scenic arts, and to provide specialised, certified training in the provision of up-to-date, inclusive arts accessibility. To fulfil these aims the ACT project has: defined the skills and competences of the two complementary roles of access coordinator and access manager, developed a curriculum for their training, and created a MOOC on arts accessibility which will be discussed further in this section. In addition to providing new content, the training also embraces some of the new technologies that allow trainers to expand education beyond the traditional borders of educational institutions.

As we already mentioned, studies on accessibility carried out within AVT have been separated from accessibility studies in other fields and have concentrated heavily on providing access to content through access services such as audio description or subtitling for the deaf and hard-of-hearing. However, within the ACT project accessibility is seen as a more complex process in which the provision of access services is just one of the many steps. To embrace the complexity of accessibility provision the project was carried out by a balanced, multisectoral consortium of nine partners: four universities (Autonomous University of Barcelona, University of Antwerp, University of Vienna and Queen's University Belfast), two theatres (NTGent and Trànsit Projectes), two departments of culture in local governments (Department of Culture of the Government of Catalonia and Inter, an accessibility agency in Flanders) and one quality agency (European Certification and Qualification Association). What is more, to guarantee input from the different actants in the accessibility chain, project outcomes were evaluated by all stakeholders involved at every stage of the project. 


\subsubsection{Curriculum design}

In the ACT project the concept of translation as such goes beyond its traditional understanding and evolves into media accessibility which encompasses more than 'just' providing access to content. The curriculum designed within the project reflects this broad framework and tries to bridge the gap between what is traditionally seen as architectural access services and media access as developed from translation through the evolution of translation into media access and now beyond (see section 2).

The first two steps towards drafting the curriculum were accessibility profiling and defining the new professional. As mentioned in section 4.1, accessibility profiling consisted of mapping the current context of cultural accessibility to identify gaps, as well as examples of good practice. Arts venues, arts users (with and without disabilities) as well as artistic teams (e.g. directors, dramaturges, actors) participated in an extensive cross-country study during which quantitative and qualitative data were gathered using a mixed methods design which included questionnaires, interviews and focus groups. In addition to the finding discussed in section 4.1 that arts accessibility management is currently inadequate and fragmented, the study also showed that access services associated with physical disability are more developed. Thus, in order to achieve quality and equality of cultural access for all it is necessary to raise awareness among venues and the general public about the less common access services; i.e., those for users with sensory, linguistic and cognitive disabilities, and how they relate to the architectural access services that are better known (Eardley-Weaver n.d.; Orero 2017). Results also confirmed the need for accessibility training since currently access to it is limited.

All partners worked together, drawing on each other's expertise, in order to define the new double professional profile: the accessibility coordinator ${ }^{5}$ and the accessibility manager ${ }^{6}$. These were rendered in detail in skill cards that were subsequently used to design the MOOC (Orero 2017). The basic skills of coordinator and manager are the same: they should understand the basic concepts of inclusion and accessibility as well as accessible events in terms of venue accessibility, accessibility services, accessibility management and promotion. The difference between the two professions lies in the context in which they operate: while the accessibility coordinator is employed at a specific venue,

5. See accessibility coordinator skills card: http://pagines.uab.cat/act/sites/pagines.uab.cat. act/files/io2-skill-cards_1_accessibility-coordinator-venue-based-_final-1.pdf

6. See accessibility manager skills card: http://pagines.uab.cat/act/sites/pagines.uab.cat.act/ files/io2-skill-cards_2_accessibility-manager_final.pdf 
the accessibility manager is not based in any one venue and may be involved in coordinating accessibility at various venues, either through collaboration with in-house accessibility coordinators or overseeing accessibility in venues where there is no accessibility coordinator (ACTa n.d).

The aim of the curriculum developed within the ACT project (ACTb n.d.) is to train professionals who combine in-depth knowledge of the requirements for ensuring inclusive access to live events in the scenic arts, with the interpersonal, managerial and practical competences required to implement them. Future accessibility coordinators and managers will be able to assess the accessibility of both the route(s) to the venue(s) and of the venue(s) at which the event is to take place. They will also be able to efficiently organise pre-performance and post event communication and content-related access as well as performance accessibility services for all audiences. Finally, they will be able to apply their skills in different contexts, transferring the skills learnt in the programme to the quickly changing cultural scene and its many creative outputs.

The training proposed by the ACT project can follow one of two paths (Orero 2017). The first one proposes training at university level: a shorter postgraduate programme leading to a degree in Accessibility Coordination and a longer master's programme which will yield the title of Accessibility Manager for the Scenic Arts. However, it is important to realise that in many cases accessibility training does not start from scratch. Many venues and their personnel are already involved in providing accessibility at least to some extent. Others will soon have to provide it in order to comply with legal or audience requirements. Both require training for in-house employees to provide quality access services. Accessibility professionals currently working in venues have already acquired knowledge from previous training or simply from professional practice. However, they may not have all the necessary skills and probably do not perceive accessibility within the framework of (intersemiotic) translation. On the other hand, venues that do not offer any accessibility services at present might want to add the accessibility manager profile to the profiles of the professionals they already employ, thereby converging translation skills (or broader content-related skills) with other skills pertaining to access services. In order to provide a viable training solution, it is thus important to devise forms that can meet the degree of flexibility required by the market without foregoing quality. Here too digitization comes to the rescue.

The second path developed within the ACT project is a MOOC for the training of an accessibility manager that can be taken by actors in the cultural sector (e.g. in theatres) wishing to expand their skills but that can also be integrated with existing courses at university or on the job, in part or in its 
entirety. An important feature of the MOOC is that it is flexible and modular. This enables a personalized and autonomous learning process for people with various experiences and levels of knowledge. The content of the MOOC was created in several of the languages of the project (e.g. English, Catalan and Dutch) with subtitles in English. The MOOC will also be fully accessible and freely available.

\subsubsection{Developing a massive open online course}

The MOOC (ACTc 2017) consists of an introductory unit, five core units and a final assessment task. It takes twelve weeks to complete the entire course. Given the fact that MOOCs, although increasingly popular, are still relatively new, the course begins with a short introduction that provides information about what a MOOC is, what can be expected from it, and what the basic code of conduct is when participating in a MOOC. Participants are also introduced to the ACT project, the structure and the content of the MOOC and to the requirements of the final task. The introduction is followed by five core units which cover the following topics: Unit 1 - inclusion and accessibility; Unit 2 - venue accessibility; Unit $3 a$ - access services: concepts, Unit $3 b$ - access services: implementation, Unit 4 - communication and dissemination, and Unit 5-management and event planning. After Unit 5, the participants have time to carry out the final assessment task which consists of creating a complete scenario of an accessible event for a chosen venue. In this way the MOOC may very well be the first to combine two hitherto distinct forms of access: access to content and access to the venue (see Section 3).

The core units of the MOOC cover all the essential knowledge and skills that accessibility coordinators or managers must possess. Unit 1 introduces the participants to the basic concepts of disability, accessibility, inclusion, different types and degrees of disability, and public procurement. They are introduced to relevant national and international legislation and to different methods for achieving accessibility. In Unit 2 participants are acquainted with the concepts and issues to be taken into account when considering the accessibility of a venue; i.e. the accessibility requirements of accessible public transport and parking, toilets, stage, seating, rain/wind/sun shelters, signs/maps/information, lighting, furniture, circulation within the venue, and space, accessibility requirements for companions, assistance animals and the architectural risks of the venue. They also learn about health and safety requirements and emergency plans, and how to communicate those to their team and the end users. Unit 3a introduces and defines the concepts of the different accessibility services and Unit $3 \mathrm{~b}$ discusses the practical steps involved in implementing the 
accessibility services, prior to the event, on the day of the performance, and after the event. Unit 4 covers all the skills related to communication with stakeholders and dissemination about an accessible event. The participants learn who the relevant stakeholders are, what the problems are with current communication channels, how to make common communication channels accessible, how to identify new communication channels and channels of user organisations and finally how to communicate about accessibility with staff, internally and externally. In Unit 5 participants acquire skills related to management and even planning: they are introduced to the core competences necessary to manage and plan an event. On the one hand, the focus will lie on theoretical knowledge about managerial skills, and on the other hand, practical exercises encourage the learners to apply this knowledge to their own situation. The topics covered in Unit 5 include planning of the pre-event tasks (e.g. budgeting, content development, venue accessibility, risk assessment, training), during-event tasks (e.g. accessibility helpdesk) and post-event task (e.g. debriefing, user feedback, venue exit).

The core units of the MOOC are planned to develop in two stages. Stage one is more theoretical while stage two focuses more on practice. During the first stage of each unit various materials are used to introduce participants to a given topic, e.g. subtitled videos and their transcriptions, presentations and reading materials. During the second stage participants are stimulated to apply the knowledge they have acquired in the first week through exercises, assignments, case-studies and discussion. They will also be able to receive first-hand knowledge through online lectures given by an accessibility expert and/or a person working in a cultural venue who has experience in making the venue accessible. Assessment is carried out by means of quizzes, written assignments and forum discussions.

\subsubsection{Ensuring quality}

The success of the project and, ultimately, the quality of the MOOC were certainly boosted by the extensive experience of the project leader (UAB) and its partners in many other European projects in AVT and Media Accessibility. However, the participatory approach pursued at all stages of the ACT project itself was also crucial. As already mentioned, an extensive analysis of current users, technology and venues was carried out prior to defining the new professional profiles. The resulting skills cards were also consulted with all the stakeholders, including all the actants in the scenic arts accessibility provision chain. This allowed the project team to identify the core skills and competences accessibility professionals require and propose a comprehensive skill set for 
implementation, not only in the current MOOC, but also in venues for the scenic arts across Europe. When it comes to the MOOC itself, it was designed together by all the partners of the ACT project, who represent three crucial fields: education, the scenic arts and policy makers. Moreover, the MOOC was tested with accessibility managers, theatre companies, providers of accessible content, and last but not least end users of cultural events, such as blind and partially sighted audiences, older people or people with learning difficulties.

\section{Concluding thoughts}

The challenges translation and its derivatives pose today for research, practitioners and training require out-of the-box thinking. AVT has come a long way from being TS's outsider, studying technology-driven translation forms such as subtitling and dubbing, thereby questioning traditional TS concepts such as "equivalence" from the very start. The many actors and actants that determine how we translate and communicate more generally have prompted the discipline to evolve along this path and to embrace the study and training of communication forms that are a very far cry from Jakobson's (1959) "translation proper". As we stated in our introduction, the authors believe that there is no such thing as "translation proper": translation continues to emerge and take on new shapes, which some may not (wish to) recognize as translation. We believe however, that translation is not a matter of belief. It is a matter of what is out there, what actants make of it and require. We need to take on these new forms of translation, communication and management in all their complexity if we are to keep abreast of change, or at least, on a par with change, and prepare our students for the society in which they will have to operate and live.

This change also makes interdisciplinarity a necessity: in those who become translator-managers, in researchers and in those who design training. The ACT team accomplished this and the very mix of professionals involved in it guarantees the interdisciplinarity of the MOOC itself. At present, it exists in two forms: the MOOC developed within the project and a form adapted to the MOOC requirements of the Coursera platform, that will have been launched as this article goes to press.

The challenge for the future is to remain open to further developments, to accept complexity as complexity in translation, and to monitor the impact of new actants on the forms it may take. 


\section{References}

AbDallah, Kristiina. (2011) "Quality Problems in AVT Production Networks: Reconstructing an Actor-Network in the Subtitling Industry." In: Serban, Adriana; Anna Matamala \& Jean Marc Lavaur (eds.) 2012. Audiovisual Translation in Close up. Frankfurt: Peter Lang.

BuZELIN, Hélène. (2005) "Unexpected Allies. How Latour's Network Theory Could Complement Bourdieusian Analyses in Translation Studies." The Translator 11:2, pp. 193-218.

EARdley-Weaver, Sarah. (n.d.) Intellectual Output 1: Accessibility Profiling. Electronic version: <http://pagines.uab.cat/act/sites/pagines.uab.cat.act/files/ act-iol-report-1-ed_sew.pdf>

EARDLEY-WEAVER, Sarah. (2013) "Opening eyes to opera. The process of translation for blind and partially-sighted audiences." Translation and Interpreting Studies. The Journal of the American Translation and Interpreting Studies Association 8:2, pp. 272-292.

EARDley-WeAVER, Sarah. (2014) Lifting the Curtain on Opera Translation and Accessibility: Translating Opera for Audiences with Varying Sensory Ability. Durham: Durham University. Unpublished PhD thesis. Electronic version: $<$ http://etheses.dur.ac.uk/10590/>

EARdley-Weaver, Sarah. (2015a) "Opera (Sur)titles for the Deaf and the Hardof-Hearing." In: Díaz-Cintas, Jorge \& Joselia Neves (eds.) 2015. Audiovisual Translation: Taking Stock. Newcastle upon Tyne: Cambridge Scholars Publishing, pp. 261-272.

EARdLEy-Weaver, Sarah. (2015b) "Knowledge Exchange Seminar Series (KESS). Including all: Improving arts accessibility for people with varying visual and hearing ability." Electronic version: <http://www.niassembly.gov.uk/ globalassets/documents/raise/knowledge_exchange/briefing_papers/series4/ sew-kess-policy-briefing-ed..pdf>

EARDLEY-WEAVER, Sarah. (2016) Accessible Culture and Training (ACT). Defining the Profession: Questionnaire Outcome from 4 EU Countries. Electronic version: $<$ http://pagines.uab.cat/act/sites/pagines.uab.cat.act/files/sew-berlin-ppp1.compressed.pdf>

FLETCHER-WATSON, Ben. (2015) "Relaxed performance: audiences with autism in mainstream theatre." Scottish Journal of Performance 2:2, pp. 61-89.

Folaron, Deborah \& Hélène Buzelin. (2007) "Introduction. Connecting Translation and Network Studies." Meta. Translators' Journal 52:4, pp. 605-642. Holmes, James. (1972) "The Name and Nature of Translation Studies." In: Holmes, James 1988. Translated!: Papers on Literary Translation and Translation Studies. Amsterdam: Rodopi, pp. 66-80. 
JAKOBSOn, Roman. (1959) "On Linguistic Aspects of Translation." In: Brower, Reuben Arthur (ed.) 1959. On Translation. Cambridge: Harvard University Press, pp. 232-239.

Kempe, Andy. (2015) "Introducing Children with Special Educational Needs to Theatre through 'Relaxed Performances'.” In: Schonmann, Shifra (ed.) 2015. International Yearbook for Research in Arts Education 3/2015: The Wisdom of the Many - Key Issues in Arts Education. Münster \& New York: Waxmann, pp. 278-284.

LATOUR, Bruno. (2005) Reassembling the Social. An Introduction to Actor-NetworkTheory. Oxford: Oxford University Press.

LINELL, Per. (2009) Rethinking language, mind and world dialogically. Interactional and contextual theories of human sense-making. Charlotte: Information Age Publishing.

LuYKEN, Georg-Michael; Thomas Herbst; Jo Langham-Brown; Helen Reid \& Hermann Spinhof. (1991) Overcoming language barriers in television: dubbing and subtitling for the European audience. Manchester: European Institute for the Media.

Rose Connell, Bettye; Mike Jones; Ron Mace; Jim Mueller; Abrir Mullick; Elaine Ostroff; Jon Sanford; Ed Steinfeld; Molly Story \& Gregg Vanderheiden. (1997) The principles of universal design. Electronic version: <https://projects.ncsu. edu/design/cud/about_ud/udprinciplestext.htm>

MARAIS, Kobus. (2013) "Exploring a conceptual space for studying translation and development." Southern African Linguistics and Translation Studies 31:3, pp. 403-414.

MARAIS, Kobus. (2014) Translation Theory and Development Studies. New York: Routledge.

ORERO, Pilar. (2017) "The professional profile of the expert in media accessibility for the scenic arts." Rivista internazionale di tecnica della traduzione 19, pp.143-161.

RISKU, Hanna \& Florian Windhager. (2013) "Extended Translation: A Sociocognitive Research Agenda." Target 25:1, pp.33-45.

SCHWAB, Klaus. (2016) The Fourth Industrial Revolution. New York: Random House. Several authors (ACT). (n.d.) Accessibility Coordinator - Skills Card. Electronic version:<http://pagines.uab.cat/act/sites/pagines.uab.cat.act/files/io2-skillcards_1_accessibility-coordinator-venue-based-_final-1.pdf>

SEVERAl AUTHORS (ACTb). (n.d.) IO3 Curriculum Design. Electronic version:<http:// pagines.uab.cat/act/sites/pagines.uab.cat.act/files/io3-university-degree-based-curriculum-design_final-draft-2.pdf>

SEVEral aUthors (European Commission). (n.d.) United Nations Convention on the Rights of Persons with Disabilities. Electronic version: <http://ec.europa.eu/ social/main.jsp? catId=1138\&langId=en> 
SEVERAl Authors (United Nations). (2008) Convention on the Rights of Persons with Disabilities. Electronic version: <http://www.un.org/disabilities/convention/ conventionfull.shtml>

SEVERAL AUthors (European Parliament and Council). (2010) European Audiovisual Media Services Directive. Electronic version: <https://eur-lex.europa.eu/ legal-content/EN/TXT/HTML/?uri=CELEX:32010L0013\&from=EN>

SEVERAL AUTHORS (European Commission). (2011) EU ratifies UN Convention on disability rights. Electronic version: <http://europa.eu/rapid/ press-release_IP-11-4_en.htm>

SEVERAL AUthors (European Parliament and Council). (2015) European Accessibility Act. Electronic version: <http://eur-lex.europa.eu/legal-content/ EN/TXT/?uri=COM:2015:0615:FIN>

SEVERAL AUTHORS (European Parliament). (2016) Online public services to be made more accessible for the disabled and elderly. Electronic version: <http://www. europarl.europa.eu/news/en/press-room/20161020IPR47872/online-publicservices-to-be-made-more-accessible-for-the-disabled-and-elderly>

SEVERAL AUTHORS (ACTc). (2017) The ACT MOOC: provisional structure. Electronic version: <http://pagines.uab.cat/act/sites/pagines.uab.cat.act/files/provisional-mooc-structure-08032017.pdf>

SEVeral Authors (Eurostat). (2017) Population structure and ageing. Electronic version: <http://ec.europa.eu/eurostat/statistics-explained/index.php/ Population_structure_and_ageing>

SNELL-Hornby, Mary; Franz Pöchhacker \& Klaus Kaindl (eds.) (1994) Translation Studies: An Interdiscipline. Amsterdam: John Benjamins.

SPIERS, Adam; Janet van der Linde; Maria Oshodi; Sarah Wiseman \& Aaron Dollar. (2015) Flatland: an immersive theatre experience centered on shape changing haptic navigation technology. Electronic version: <http://oro.open. ac.uk/42647/8/Flatland_World_Haptics_Spiers_2015.pdf>

SzARKOWSKA, Agnieszka; Anna Jankowska; Krzysztof Krejtz \& Jarosław Kowalski. (2016) "Open Art: Designing Accessible Content in a Multimedia Guide App for Visitors with and without Sensory Impairments." In: Matamala, Anna \& Pilar Orero (eds.) 2016. Researching Audio Description: New Approaches. London: Palgrave Macmillan, pp. 301-320.

TYMoczKo, Maria. (2007) Enlarging Translation, Empowering Translators. St. Jerome: Manchester.

Wiseman, Sarah; Janet van der Linden; Adam Spiers \& Maria Oshodi. (2017) Control and Being Controlled: Exploring the use of Technology in an Immersive Theatre Performance. Electronic version: <http://oro.open.ac.uk/49339/1/dis2017FlatlandCamReadyApr.pdf> 


\section{BIONOTAS / BIONOTES}

Aline RemaEl is Professor of Translation Theory, Interpreting and Audiovisual Translation at the Department of Applied Linguistics/Translators and Interpreters. Her main research interests are audio-visual translation (intra- and interlingual subtitling), media accessibility (audio-description and audio-subtitling) and new hybrid forms of interpreting that have affinities with AVT. She was a partner in the European ADLAB project, is currently supervising a Flemish funded project on accessible theatre, and is a partner in three Erasmus+ projects on accessibility and training: ACT, ADLAB PRO and ILSA. She supervises PhDs in AVT, Media Access and Remote Interpreting. She has organized numerous international conferences, including the new symposium series entitled "Unlimited! Live accessible events", launched at UAntwerp in April 2016. She is a member of the editorial board of various international Translation Studies journals, a member of the International TransMedia Research Group, and board member of ENPSIT (European Network for Public Service Interpreting and Translation).

Aline Remael es profesora de Teoría de la Traducción, Interpretación y Traducción Audiovisual en el Departamento de Lingüística Aplicada / Traductores e Intérpretes. Sus principales intereses de investigación son la traducción audiovisual (la subtitulación intra e interlingüística), la accesibilidad a los medios (la audiodescripción y el audiosubtitulado) y las nuevas formas híbridas de interpretación que tienen afinidades con AVT. Participó en el proyecto europeo ADLAB (www.adlabproject.eu). Actualmente supervisa un proyecto financiado en Flandes sobre el teatro accesible y participa en tres proyectos Erasmus+ sobre la accesibilidad y la formación: ACT, ADLAB PRO e ILSA. Supervisa doctorados en AVT, accesibilidad e interpretación a distancia. Ha organizado numerosas conferencias internacionales, incluida la nueva serie de simposios titulada "Unlimited! Live accessible events", lanzada en UAntwerp en abril de 2016. Es miembro del consejo editorial de varias revistas internacionales de Traducción, miembro del grupo internacional de investigación TransMedia Research Group y miembro del consejo de ENPSIT (European Network for Public Service Interpreting and Translation).

Pilar Orero teaches at Universitat Autònoma de Barcelona (Spain). Leader of numerous research projects funded by the Spanish and Catalan Gov. She led TransMedia Catalonia http://grupsderecerca.uab.cat/transmediacatalonia, the European Master in Audiovisual Translation and various EU projects (e.g. HBB4ALL, 2013-2016). She led Audio Description in the working group at 
UN agency ITU 2011-2013 on Media accessibility and is now participating in the IRG-AVA - Intersector Rapporteur Group Audiovisual Media Accessibility. She worked on the Audio Description standard ISO/IEC JTC 1/SC 35 N. She has held the INDRA Accessible Technologies Chair since $2012 \mathrm{http} / / / \mathrm{www}$. tecnologiasaccesibles.com/en/university_collaboration.htm and leads the EU project KA2 ACT (2015-2018).

Pilar ORERO es profesora en la Universitat Autònoma de Barcelona e investigadora principal de numerosos proyectos financiados por los gobiernos de España y Cataluña. Dirigió el grupo de investigación TransMedia Cataluña (http:// grupsderecerca.uab.cat/transmediacatalonia), Máster Europeo en Traducción Audiovisual y varios proyectos europeos (p.ej. HBB4ALL, 2013-2016). Dirigió Audio Description en el grupo de trabajo de la agencia de las Naciones Unidas ITU 2011-2013 sobre la accesibilidad a los medios y ahora está participando en el IRG-AVA - Intersector Rapporteur Group Audiovisual Media Accessibility. Ha sido coeditora del estándar ISO/IEC JTC 1/SC $35 \mathrm{~N}$ de audiodescripción. Desde 2012 ocupa la Cátedra INDRAdecco en Tecnologías Accesibles (http:// www.tecnologiasaccesibles.com/es/university_collaboration.htm). Es investigadora principal del proyecto europeo ACT (2015-2018).

Sharon Black is Research Fellow and Project Coordinator for the Accessible Culture and Training (ACT) project at Queen's University Belfast. She also teaches Simultaneous Interpreting, Consecutive Interpreting, Commercial Interpreting and Public Service Interpreting on the MA in Interpreting programme and Spanish translation workshops for students of the MA in Translation. Her teaching is informed by her ongoing professional practice as a conference and public service interpreter and translator (specialising in Spanish and French). Her principal research interests lie in the fields of audiovisual translation, particularly the reception of translated audiovisual content, cognitive translation studies, and cultural and media accessibility. From September 2018 she will be a Lecturer in Interpreting with Spanish at the University of East Anglia.

SHARON BLACK es investigadora y coordinadora del proyecto ACT en Queen's University Belfast. Es profesora de interpretación simultánea, interpretación consecutiva, interpretación comercial e interpretación para los servicios públicos en el programa de Máster de Interpretación y de traducción (español/ inglés) en el Máster en Traducción. Su enseñanza se basa en su práctica profesional continua como traductora e intérprete de conferencias y servicios públicos (especializada en español y francés). Sus principales intereses de 
investigación se basan en la traducción audiovisual, particularmente la recepción del contenido audiovisual traducido, los estudios cognitivos de traducción y la accesibilidad a las artes y a los medios. A partir de septiembre de 2018 será profesora de interpretación de español en la Universidad de East Anglia.

ANNA JANKOWSKA is Assistant Lecturer in the Chair for Translation Studies and Intercultural Communication at the Jagiellonian University in Krakow (Poland) and visiting scholar at the Universitat Autonoma de Barcelona within the Mobility Plus program of the Polish Ministry of Science and Higher Education (2016-2019). Her main research interests are accessible technologies, translation of audio description scripts, cognitive aspects of audio description process and multiculturalism in audio description. She was the leader of the project AudioMovie - Cinema for All financed by the Polish National Centre For Research and Development and participated in numerous projects funded by Polish government and the EU (e.g. OpenArt, PICT). Currently she is leading the ADDit! project and is involved in the ADLAB PRO and NEA projects. She is also the founder and president of the Seventh Sense Foundation which provides audio description and subtitles for the deaf and hard of hearing for live events and cinemas.

ANNA JANKOWSKa es profesora adjunta de la Cátedra de Traducción y Comunicación Intercultural de la Universidad Jagellónica de Cracovia (Polonia) y profesora visitante en la Universitat Autònoma de Barcelona dentro del programa Mobility Plus del Ministerio de Ciencia y Educación Superior de Polonia (2016-2019). Sus principales intereses de investigación se basan en las tecnologías accesibles, la traducción de guiones de audiodescripción, los estudios cognitivos del proceso de la audiodescripción y el multiculturalismo en la audiodescripción. Fue la investigadora principal del proyecto AudioMovie Cinema for All, financiado por el Centro Nacional de Investigación y Desarrollo de Polonia y participó en numerosos proyectos financiados por el gobierno polaco y la UE (p.ej. OpenArt, PICT). Actualmente, es investigadora principal del proyecto ADDit! y participa en los proyectos ADLAB PRO y NEA. También es la fundadora y presidenta de la Fundación Seventh Sense, que ofrece audiodescripciones y subtítulos para eventos en vivo y cines. 